\title{
Teachers' Attitudes towards Including Students with Emotional and Behavioural Difficulties in Mainstream School: A Systematic Research Synthesis
}

\author{
Ulrika Gidlund \\ Mid Sweden University \\ Sundsvall, Sweden
}

\begin{abstract}
Previous research reviews on teachers' attitudes towards inclusive education have shown that students' types of special educational needs influences teachers' attitudes; these reviews have also indicated that, in terms of the inclusion of various groups, teachers are most negative about including students with behavioural problems. This article is a review of the research on teachers' attitudes towards inclusion with regard to students who have special educational needs. It specifically identifies evidence regarding teachers' attitudes towards the inclusion of students with emotional and behavioural difficulty (EBD). For this review, 15 studies, measuring teachers' attitudes from 15 countries, met the inclusion criteria. The results of this synthesis confirmed that most teachers hold negative attitudes towards the inclusion of students with EBD; however, this was not true in all countries. The results also highlight specific explanations for why teachers hold negative attitudes towards including students with EBD in their classrooms. The implication of this synthesis is that teachers feel that their prerequisites for successfully including students with EBD are not being met; this impracticability is most impactful when the teachers nevertheless try to include these students.
\end{abstract}

Keywords: emotional and behavioural difficulties; inclusion; special educational needs; teachers' attitudes.

\section{Introduction}

Several international documents describe the right to education as applying to all children, including those who have significant needs for special support. The concept of inclusive education won international recognition when the United Nations Educational, Scientific, and Cultural Organisation (UNESCO) put forth the idea of "Education for All" in 1990. Several countries have since 
implemented policies to promote integration and to include these students in regular schools. Neither teachers nor schools have developed or even agreed to the concept of inclusion. This concept originated as a political initiative in human rights, and it has been passed down from the United Nations to national and local governments and then to schools. The teachers are yet the ones to implement this policy, which makes their attitudes greatly important to the successful implementation of inclusion, which also is emphasized in the Salamanca Statement (UNESCO 1994). However, it is not clear how teachers' attitudes vary in relation to the students' specific types of special educational need (SEN). In the following sections, the multiple definitions and floating meanings of inclusion and of emotional and behavioural difficulty (EBD) will be presented, followed by a presentation of some older reviews of teachers' attitudes towards inclusion (Avramidis \& Norwish, 2002; Bowman, 1986; de Boer, Pijl, \& Minnaert, 2011; Leyser, Kapperman, \& Keller, 1994; Scruggs \& Mastropieri, 1996), which serve as a basis for this study.

\section{Inclusion}

Internationally, in the last 25 years, the concept of inclusion has come to signify the development of "Education for All" (UNESCO, 1990). This concept originated in sociology but is often used in special educational settings. The ideas at the core of the concept are related to human rights, equal opportunity, and social justice; it arose during the 1990s as a core question in political and educational theory, and it has since been the focus of some of the tensest debates in education. Today, most people agree that education should recognize diversity and therefore be inclusive; Enslin and Hedge (2010) provided a historical overview of the changes in the perceptions of inclusion and diversity that have occurred over the last 70 years.

The term inclusion replaced integration, but the newer term has a broader meaning that embraces both social disadvantage and SEN; while inclusion is often contrasted with exclusion. Integration dealt mostly with disability and SEN, but inclusion is usually promoted from a wider perspective that is principled and idealistic - or even ideological (Evans and Lunt 2002). The term mainstreaming is also used interchangeably with integration, but with a narrower meaning focused on integrating students who have disabilities into generaleducation classes (Scruggs \& Mastropieri, 1996) at specific times based on their skills.

It is important to stress that inclusive education comprises much more than integration does. Thomas and Loxley (2001) claimed that inclusive education deals less with the SEN of the students and more about developing an education system that strives for human rights.

\section{Emotional and Behavioural Difficulty}

$E B D$ is one of several terms for the same concept. In England, EBD is used interchangeably with the terms social, emotional, and behavioural difficulty (SEBD) and behavioural, emotional, and social difficulty (BESD, both of which also include social difficulty. Regardless, EBD is an umbrella term, which makes it difficult to define; however, it typically refers to the risks of school problems and further social exclusion (Department for Education, 1994). UNESCO (2009) also described the concept of SEBD as an imprecise umbrella term, difficult to define 
since it vary in behaviours that challenges teachers; for example, passive, depressive, or aggressive behaviour. However, what is considered socially acceptable behaviour will vary enormously from one cultural, religious and traditional context to another. Social, emotional and behavioural difficulties are therefore strongly influenced by the background and situation of the specific child.

Sweden's National Board of Health and Welfare (2010) defined behaviour problems similarly, as repeated violations of the rules, norms, or expectations of a childhood environment. Most behaviour problems are defined in terms of the values and norms of a social community. A child's action could be perceived as a problem in one situation (e.g., as a protest against a teacher in the classroom) but not in another (e.g., as a protest against a bully); (National Board of Health and Welfare, 2010). Students with EBD often experience difficulties with concentration, motivation, and adaptation in regular school settings (Stoutjesdijk, Scholte, \& Swaab, 2016). Relative to other students, those with EBD are also more likely to drop out of school and thus less likely to complete high school and attain higher education (Maggin et al., 2016). Many of these students, therefore, receive relatively low academic grades, and they often experience more social exclusion than either nondisabled students or those with other types of SEN.

In summary, neither inclusion nor EBD has a clear, universal meaning. Both concepts are highly influenced by context, cultural traditions, and national policymaking, resulting in multiple interpretations and causing teachers to feel insecure about how to handle inclusion and EBD.

\section{Teachers' Attitudes}

Previous comparative research and literature reviews have revealed complexity in teachers' attitudes towards inclusion, integration, and mainstreaming. The following is a short presentation of the reviews, and studies that frame this study's aims and its search criteria.

In the earliest study on this topic, Bowman (1986) examined integration in 14 nations across UNESCO's five regions and focused on, for instance, teachers' attitudes towards mainstreaming. Approximately 1,000 teachers who had experienced teaching students with SEN participated in Bowman's study; were from Australia, Botswana, Colombia, Czechoslovakia, Egypt, Italy, Jordan, Mexico, Norway, Portugal, Senegal, Thailand, Venezuela, and Zambia. Bowman found significant differences in these teachers' attitudes, the most notable of which is that teachers from countries where integration was required by law had more favourable attitudes than those from other countries. Teachers also had more positive attitudes regarding the integration of students with physical and sensory impairments than of those with learning difficulty or EBD (Bowman, 1986).

In the second study, Leyser et al. (1994) compared attitudes towards mainstreaming and integration among teachers from six nations-Germany, Ghana, Israel, the Philippines, Taiwan, and the United States. Leyser et al. revealed that there were differences in the teachers' attitudes towards integration across these countries. Several variables, such as training in special 
education, grade level, age, teaching experience, and experience with disabled people, were associated with the teachers' attitudes.

In the third study, Scruggs and Mastropieri (1996) published the first comprehensive research synthesis on teachers' attitudes towards mainstreaming and inclusion. Scruggs and Mastropieri included 28 reports (published from 1958 through 1995) with a total of 10,560 respondents (including both teachers and other school personnel) from the United States, Australia, and Canada. One significant finding of Scruggs and Mastropieri's study was that teachers had more negative attitudes towards more severe disabilities because the teachers feared that students with severe disabilities would destroy the learning environment for the entire class. Another important finding was that school administrators and college faculty members each held more positive attitudes than classroom teachers did (Scruggs \& Mastropieri 1996). The Scruggs and Mastropieri study is more than 20 years old, and it covers studies from almost 40 years, but it showed no systematic relation between the teachers' attitudes and the study's date of publication. Very little changed in terms of teachers' attitudes are detected during those years.

The fourth study, Avramidis and Norwish (2002), reviewed studies on teachers' attitudes towards both integration and inclusion. Avramidis and Norwish's main finding was that teachers' attitudes towards inclusion are largely based on the type and severity of students' disabilities. Teachers had more positive attitudes towards the inclusion of students with mild disability (e.g., a physical or sensory disability) than towards the inclusion of students with severe learning or behavioural difficulty (Avramidis \& Norwish, 2002). This study indicated that teachers' attitudes towards the inclusion of students with SEN in mainstream schools depended on a variety of factors: (a) the nature of the disability; (b) the teacher's gender, teaching experience, grade level taught, and SEN-specific experience and training; and (c) the available support services at the classroom and school levels.

Finally, de Boer et al., (2011) presented an overview of 26 empirical studies published between 1998 and 2008, revealing that most teachers held neutral or negative attitudes towards the inclusion of students with SEN in regular education. None of the studies in de Boer et al.'s review reported clearly positive results, even though the teachers claimed that they were positive towards inclusive education - just not in their own classrooms. The results of de Boer et al.'s study also indicated that teachers' attitudes are related to the type of disability, as earlier researchers had also stated. Teachers held the strongest negative attitudes towards the inclusion of students with learning disabilities and those with ADHD or other behaviour problems, and they held the strongest positive attitudes towards the inclusion of students with physical and sensory disabilities (de Boer et al., 2011).

To summarize, the researchers in the above studies indicated that teachers' attitudes towards the inclusion of students with SEN in mainstream schools depend on a variety of factors - most importantly, the type and severity of the disability. The researchers concluded that teachers' attitudes towards inclusion are most strongly negative regarding students who have severe learning or behaviour problems. 
The present research synthesis is intended to go beyond the individual studies on teachers' attitudes, and to synthesize the research on teachers' attitudes towards the inclusion of students with SEN (particularly those with EBD), and to carefully explore the explanation the teachers state affect their attitudes, as those explanations have not previously been synthesized. The research on teachers' attitudes is highly relevant because problems concerning the implementation of full inclusion still remain questionable. The specific reasons that teachers mention when explaining why they hold negative attitudes towards the inclusion of students with EBD in their classrooms are synthesized and explored. To this point the study's research questions are:

- What attitudes do teachers have towards the inclusion of students with EBD in mainstream schools?

- Which explanation do the teachers state affect their attitudes towards the inclusion of students with EBD in mainstream schools?

When implementing reform recommendations, it is very important to focus on teachers' attitudes. If the wish is to discuss, challenge, and redirect these attitudes, however, it is even more important to examine the factors behind such attitudes.

\section{Methods}

Descriptive research synthesis relies on explicit search strategies and on unambiguous criteria for selecting pertinent, high-quality studies. It is systematic, explicit, comprehensive, and reproducible, and it relies on knowledge, evidence, and experience to identify and interpret similarities and differences in the studies' purposes, methods, and findings (Fink, 2005). But, a research synthesis is only one of several possible constructions of the research area (Nilholm, 2017). The theoretical point of departure of this study is that the concept of inclusion and EBD are regarded as something socially constructed with multiple interpretations and floating meanings due to context, cultural traditions, and national policymaking. This research synthesis involved multiple phases to identify the studies dealing with the research questions, and the recommendation of PRISMA statements were followed (PRISMA, 2014), and these phases will be presented in separate sub-headings.

\section{Identification}

An initial identification of potential studies was conducted via an advanced keyword search of the SCOPUS database in January 2017. SCOPUS was chosen because it is the world's "largest abstract and citation database of peer-reviewed research literature" (Elsevier, 2017) with over 22,000 titles from more than 5,000 international publishers, and studies from different countries were needed. Firstly, a broad search (using the keywords from the research questions) was used to establish the main outline of the study. Only English-language, peerreviewed articles from the social sciences were included. This broad search resulted in too many articles, which led to a series of more detailed searches, starting with an initial sift on the titles of the articles found in the broad search.

So as not to miss out on any relevant articles, key journals and other relevant articles' reference lists were also searched by hand. The key words, and their thesaurus terms, used for each search were: 
1. "inclusion" and "teachers' attitudes";

2. "EBD" and "teachers' attitudes"; and

3. "EBD" and

“inclusion."

\section{Screening}

The combination of the terms "inclusion" and "teacher attitudes" resulted in 145 sources; the combination of "EBD" and "inclusion" resulted in 35 sources; and the combination of "EBD" and "teacher attitudes" resulted in three sources. To determine whether the studies' findings were comparable and compatible, the following inclusion criteria were used in the study:

- contained empirical data,

- focus on teachers' attitudes towards inclusion, and

- comparison of teachers' attitudes towards the inclusion of students with various categories of SEN in mainstream education.

Articles on the attitudes of other students, pre-service teachers, teacher students, or SENCOs were excluded, and so were also articles that not focus on primary school. For this research synthesis, articles were included only if they dealt with different categories of SEN in relation to teachers' attitudes regarding inclusion in mainstream schools.

The search returned 183 articles. After reading the titles, 109 articles were rejected because they

- did not focus on attitudes towards inclusive education;

- were about the attitudes of students, student teachers, preschool teachers, secondary-level teacher, or special education teachers;

- were limited to specific curriculum subjects;

- evaluated inclusive education interventions;

- did not focus on attitudes towards various types of SEN; or

- did not include empirical data.

\section{Eligibility}

After this first filtering, 72 articles remained (one article was found in all three searches). An additional abstract screening led to a database of 39 articles; the manual search added six more studies, for a total of 45 articles. After reading the articles carefully, 30 were rejected because they did not satisfy the selection criteria for this review question, as they included the attitudes of participants of other school types (14 studies); did not include empirical data (5 studies); compared the attitudes of people other than teachers (5 studies); did not compare different types of SEN (3 studies); or did not discuss EBD (3 studies); This led to a final database of 15 studies (see Figure 1). 


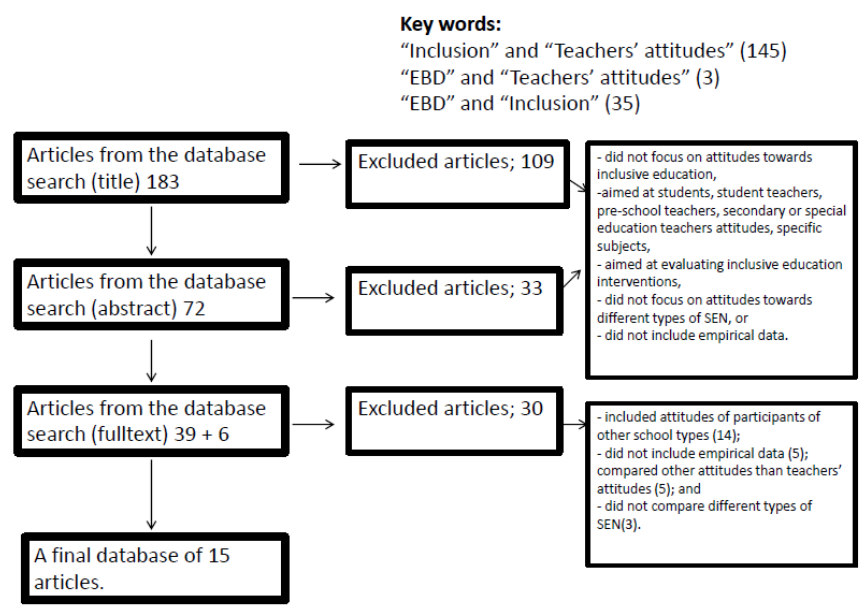

Figure 1. Overview of the review process.

To avoid missing an important study, two additional searches were conducted. The search term combinations "teachers' attitudes" and "SEN" (43 studies found) and "teachers' attitudes" and "disability" (117 studies found) were used. No new articles were added, as all of those that met the relevance criteria were already included.

\section{Including}

Because there is a lack of consensus on what counts as good-quality qualitative research and what formal criteria should be used (Boaz \& Sidford, 2006), it is important to account for the criteria used in any research synthesis. All Included articles in this research synthesis were peer reviewed and published in an international scientific journal.

A synthesis can differ based on what counts as data from the primary studies, and what not (Major \& Savin-Baden, 2010). This research synthesis considers any data presented in the articles that are relevant to the aim of this paper. The themes that run across the included articles were identified inductively; they were strongly linked to the data. The steps of constructionist thematic analysis were followed to identify these themes (Braun \& Clarke, 2006). Throughout the analytical process, the included articles (in their entirety) served as points of reference when deeper understanding was needed to define the themes.

\section{Results}

This section comprises a synthesis of the 15 articles included in this research. Each study's context, samples, methods, and findings, are presented and followed by the themes that recurrently run across the included studies regarding the teachers' explained barriers to the inclusion of students with EBD. Each theme is presented and analysed separately to reveal a new meaning.

\section{Presentation of the Included Studies}

The following is a summary of the included articles in relation to this study's aims and search criteria. Table 1 shows the 15 countries that the 15 included 
articles covered: Dubai, England, Finland, Germany, Ghana, Greece, Haiti, Lebanon, the Republic of Ireland, Russia, Scotland, Slovenia, South Africa, Turkey, and the United States. Two of these articles compared teachers' attitudes across two countries; in addition, three focused on the United States. Most of the studies were conducted from 2005 through 2016; the oldest included study is from 2001.

Table 1. Overview of the included articles

\begin{tabular}{|c|c|c|}
\hline Author & Location & SEN difficulty \\
\hline Cook (2001) & $\begin{array}{l}\text { Ohio, The } \\
\text { United } \\
\text { States }\end{array}$ & $\begin{array}{l}\text { Students with } \mathrm{ADHD}, \mathrm{BD} \text {, and } \mathrm{LD} \text { were all } \\
\text { among the most rejected by teachers. }\end{array}$ \\
\hline $\begin{array}{l}\text { Dupoux, Wolma, \& } \\
\text { Estrada (2005) }\end{array}$ & $\begin{array}{l}\text { Haiti and } \\
\text { The United } \\
\text { States }\end{array}$ & $\begin{array}{l}\text { Students with EBD were the most difficult to } \\
\text { include. }\end{array}$ \\
\hline $\begin{array}{l}\text { Avramidis \& Kalyva } \\
(2007)\end{array}$ & Greece & $\begin{array}{l}\text { EBD was not the major concern-sensory } \\
\text { impairments, brain injuries, and neurological } \\
\text { disorders were the worst. }\end{array}$ \\
\hline Gaad \& Khan (2007) & Dubai & $\begin{array}{l}\text { EBD was not the major concern; severe special } \\
\text { needs were the worst. }\end{array}$ \\
\hline Grieve (2009) & Scotland & $\begin{array}{l}\text { Students with EBD were the most difficult to } \\
\text { include. }\end{array}$ \\
\hline $\begin{array}{l}\text { Gyimah, Sugden, \& } \\
\text { Pearson (2009) }\end{array}$ & Ghana & $\begin{array}{l}\text { EBD was not the major concern; sensory } \\
\text { impairments and intellectual difficulties were. }\end{array}$ \\
\hline $\begin{array}{l}\text { Cook \& Cameron } \\
(2010)\end{array}$ & $\begin{array}{l}\text { Ohio, } \\
\text { United } \\
\text { States }\end{array}$ & $\begin{array}{l}\text { Students with EBD were the most rejected by } \\
\text { their teachers. }\end{array}$ \\
\hline $\begin{array}{l}\text { Rakap \& Kaczmarek } \\
(2010)\end{array}$ & Turkey & $\begin{array}{l}\text { Students with EBD were the most difficult to } \\
\text { include. }\end{array}$ \\
\hline $\begin{array}{l}\text { Čagran } \quad \& \quad \text { Schmidt } \\
(2011)\end{array}$ & Slovenia & $\begin{array}{l}\text { Students with EBD were the most difficult to } \\
\text { include. }\end{array}$ \\
\hline $\begin{array}{l}\text { Khochen \& Radford } \\
\text { (2012) }\end{array}$ & Lebanon & $\begin{array}{l}\text { Students with EBD were the most difficult to } \\
\text { include. }\end{array}$ \\
\hline
\end{tabular}


Bornman \& Donohue South Africa (2013)

Shevlin, W
Flynn (2013)

Monsen, Ewing, \& England Kwoka (2014)

Saloviita \& Schaffus (2016)

Chepel, Aubakirova, \& Russia Kulevtsova (2016)

Finland and Germany
ADHD was not seen as the worst condition, but students with it were the most disruptive, most impolite, and had the most negative effect on the classroom.

Students with EBD were the most difficult to include.

Students with EBD were the most difficult to include.

Yes, but the German teachers were more willing than their Finnish colleagues.

Students with EBD were the most difficult to include.

The methodologies of the studies are also varied (see table 2). One of the 15 studies was a qualitative study, 12 were quantitative, and two included both questionnaires and semi-structured interviews. Of the quantitative studies, 11 used Likert-scale instruments, and these ranged from 2 to 8 items. One study was based on observations, and one consisted only of interviews. The number of participating teachers also varied across the studies, ranging from 1,360 to only 14.

Table 2. Overview of the methodology of the included articles

\begin{tabular}{|c|c|c|c|}
\hline Author & Location & Instrument & Participants \\
\hline Cook (2001) & $\begin{array}{l}\text { Ohio, The } \\
\text { United } \\
\text { State }\end{array}$ & $\begin{array}{l}\text { A nomination form with four } \\
\text { attitudinal categories }\end{array}$ & $\begin{array}{l}70 \text { general-education } \\
\text { teachers }\end{array}$ \\
\hline $\begin{array}{l}\text { Dupoux, } \\
\text { Wolma, \& } \\
\text { Estrada (2005) }\end{array}$ & $\begin{array}{l}\text { Haiti and } \\
\text { The United } \\
\text { States }\end{array}$ & $\begin{array}{l}\text { A demographic questionnaire } \\
\text { and ORI, a 6-item Likert-type } \\
\text { scale. }\end{array}$ & $\begin{array}{l}368 \text { teachers, } \\
152 \text { from Port au } \\
\text { Prince and } 216 \text { from } \\
\text { south-eastern Florida }\end{array}$ \\
\hline $\begin{array}{l}\text { Avramidis \& } \\
\text { Kalyva (2007) }\end{array}$ & Greece & $\begin{array}{l}\text { Questionnaire and MTAI, a, 3- } \\
\text { item Likert-types scale }\end{array}$ & 155 teachers \\
\hline $\begin{array}{l}\text { Gaad \& Khan } \\
\text { (2007) }\end{array}$ & Dubai & $\begin{array}{l}\text { A two-part questionnaire, a 3- } \\
\text { item Likert-type scale, and semi- } \\
\text { structured interviews }\end{array}$ & $\begin{array}{l}n \quad 25 \text { questionnaires } \\
\text { and } n 15 \text { interviews }\end{array}$ \\
\hline Grieve (2009) & Scotland & $\begin{array}{l}\text { A questionnaire and a 5-item } \\
\text { Likert-type scale }\end{array}$ & 201 teachers \\
\hline $\begin{array}{l}\text { Gyimah, } \\
\text { Sugden, }\end{array}$ & Ghana & $\begin{array}{l}\text { A questionnaire with a } \\
\text { demographical sections and a 5- }\end{array}$ & 500 teachers \\
\hline
\end{tabular}




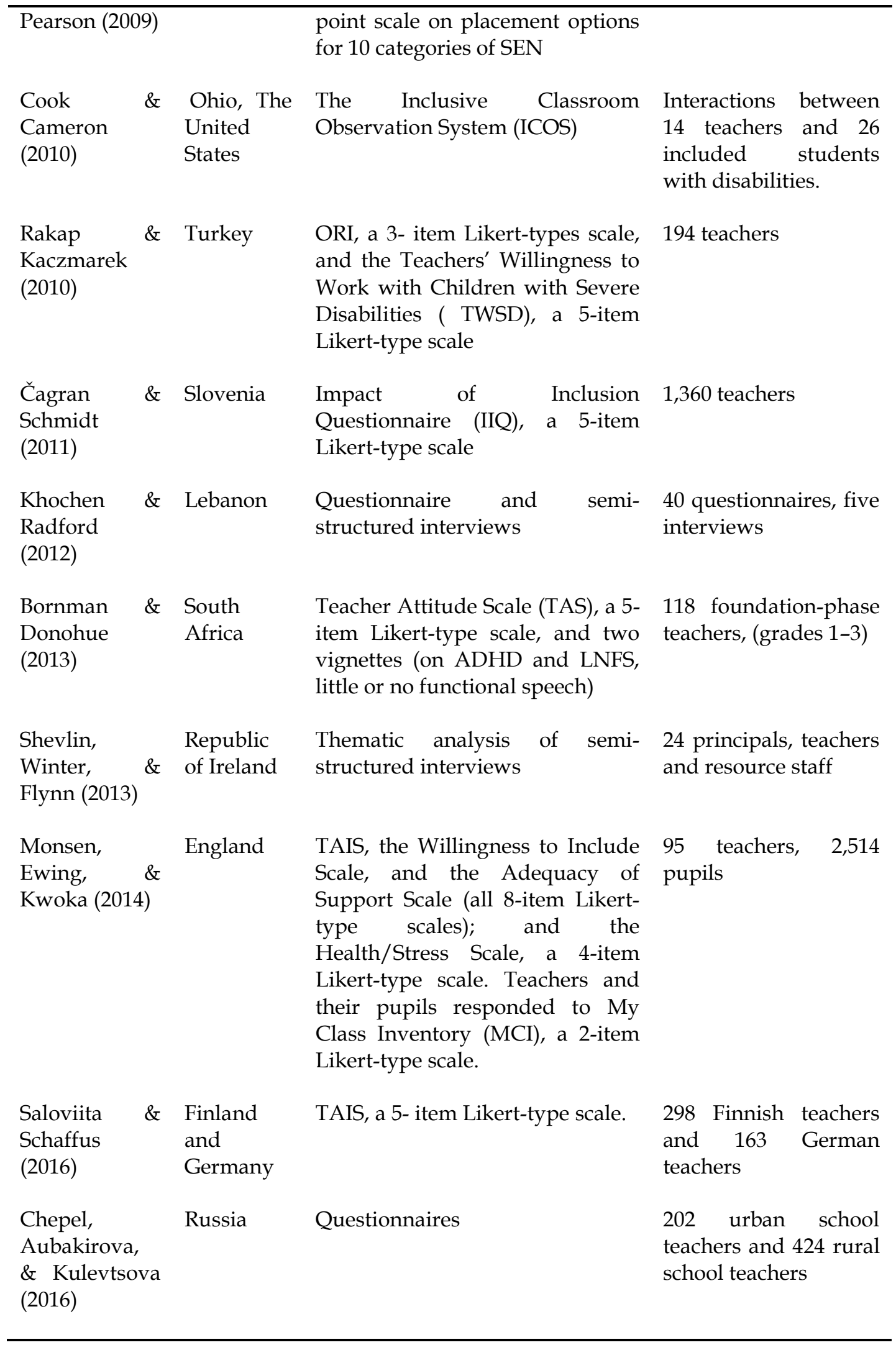

Notes: MTAI, My Thinking About Inclusion Scale (5-item Likert-type scale); ORI, Opinions Relative to the Integration of Students with Disabilities (6-item Likert-type scale); TAIS, Teacher Attitude Toward Inclusion Scale (5-item Likert-type scale). 


\section{Synthesizing Analyses}

Synthesizing research involves identifying and combining themes and categories across the included studies to create new meaning (Major \& Savin-Baden, 2010). In all the articles that were included in this study, the findings indicated that teachers' attitudes towards inclusion vary, and the types of SEN that disturbed the teachers and the class the most eliciting the strongest negative attitudes. Of the 15 studies that mentioned EBD, 10 held attitudes that EBD were the least positive. Four studies (Avramidis \& Kalyva, 2007; Bornman \& Donohue, 2013; Gaad \& Khan, 2007; Gyimah et al., 2009) found that other disabilities elicited most strongly negative attitudes than did EBD. The remaining study only listed attitudes on EBD. It did not compare attitudes towards EBD with other types of SEN (Grieve 2009). All the included articles incorporated discussions about why teachers held negative attitudes towards the inclusion of students with EBD in their classrooms even when those teachers did not consider them to be worse. Participants commonly cited the complex needs of students with EBD, but they did so in slightly different manners.

Certain themes regarding teachers' explained barriers to the inclusion of students with EBD recurrently run across the included studies. In this synthesis, those themes, which are identified and presented separately, relate to the effects that students with EBD have on (a) the classroom climate, (b) students' learning outcomes, and (c) teachers' frustration, and because of (d) the school organization (e) the attitudes of others.

\section{The Classroom Climate}

Teachers are responsible for all students in their classrooms and have to make sure that these students feel safe and secure and that the classroom climate is a good learning environment. Teachers' attitudes towards including students with SEN in the classroom vary depending on the degree of disturbance the particular type of SEN can cause the other students in the classroom.

The participants in the included studies claimed that it is difficult to control classroom behaviours when students with behaviour problems are included and that these students can cause increased disruption to classroom activities. The participants also claimed that students with EBD, result insignificantly greater disarrangement and stress than do students with other forms of SEN (Bornman \& Donohue, 2013; Gaad \& Khan, 2007; Monsen et al., 2014; Rakap \& Kaczmarek, 2010).

Some participants also accused some of the students with EBD of causing behavioural disorders and physically endangering other students, making the classroom atmosphere unpredictable and threatening which can frighten and stress out other students (Čagran \& Schmidt, 2011; Cook \& Cameron, 2010; Grieve, 2009). Participants also presented students with EBD as being much more impolite and disruptive than other students and accused them of speaking loud and unasked for, not taking turns, not participating in tasks, and not following instructions, all of which have negative effects on the classroom climate (Bornman \& Donohue, 2013; Grieve, 2009).

The participating teachers also worried about compromising the classroom activities of the majority to adapt to the minority who had EBD. The classroom climate and the other students' well-being are two of the variables that affect teachers' attitudes towards including students with SEN in their 
classrooms.

\section{Students' Learning Outcomes}

Schools all over the world have a common curriculum for all students and teachers are supposed to deliver the related skills and knowledge to their students. Individual countries also often have national tests and other inspections that ensure that students reach the expected learning goals. Some teachers fear that, by including students with EBD in mainstream classrooms, the classroom disturbances that such students supposedly cause could lower learning achievement for the other students in the class and the school as a whole.

Students with EBD could disturb other students; when classroom activities are disrupted, all students' academic achievement can decline. In other words, as Čagran and Schmidt (2011) claimed, students with EBD have a negative impact on their classmates' learning. No students learn well when discipline is undermined (Shevlin et al., 2013) and students with EBD need SEN to keep up with their classmates (Bornman \& Donohue, 2013). Some teachers explained their attitudes by referring to the inflexibility of the strict, academically orientated curriculum (Avramidis \& Kalyva, 2007; Gyimah et al., 2009; Shevlin et al., 2013). In Grieve's (2009) study, teachers in Scotland reported that inclusion of students with EBD is difficult when combined with the schools' demands to produce measurable results and learning outcomes. Russian teachers in the study by Chepel et al., (2016) claimed that teaching students with EBD also entails more complex didactic problems. Other authors described teachers' worries that disruptive behaviour could cause all students to underachieve, thus lowering their schools' scores on national tests (Khochen \& Radford, 2012; Shevlin et al., 2013).

Based on the above, a strict curriculum does not seem to be suitable for students with EBD. Teachers also express uncertainty about their ability to ensure the other students' learning outcomes. Teachers use these arguments to explain their reluctance to include students with EBD in their classrooms.

\section{Teachers' Frustrations}

The inclusion of students with EBD in mainstream classrooms makes teachers feel frustrated, discouraged, and insufficient, as they do not know how to handle students who can be both disruptive and unpredictable. Such teachers argue that having students with EBD in their classes means that they can meet neither those students' nor the other students' needs. Avramidis and Kalyva (2007) found that teachers did not hold negative attitudes towards students with EBD; rather, they felt that such problems were beyond their competence or control.

According to Cook (2001), students with hidden disabilities such as EBD are expected to behave and perform at the same level as their classmates because their disabilities cannot be explained away (as they are not visible). Teachers have reported a strong sense of frustration with regard to handling EBD students' behaviour in regular classrooms, particularly the negative effects that such behaviour has on learning outcomes. Teachers are despondent when the classroom atmosphere is unpredictable or intimidating (Čagran \& Schmidt, 2011; Cook, 2001; Chepel et al., 2016; Shevlin et al., 2013). Students with EBD also cause more teacher anxiety than other students do as they sometimes make 
unreasonable, disproportionate, or even impossible demands of their teachers. For teachers, preparing or conducting lessons that fail can have an emotional cost; they can feel like failures (Cook \& Cameron, 2010; Grieve, 2009; Rakap \& Kaczmarek, 2010; Shevlin et al., 2013). It is also stressful for teachers to consider each other's relative competence. Saloviita \& Schaffus (2016) noted that, if one teacher does well and another does not, those teachers feel that their competence is being questioned.

Several researchers have found that, compared to older teachers, younger teachers are more positive about inclusive education because their training is more up to date. At the same time, other researchers have shown that having more experience with students who have disabilities is correlated with being more cynical, burnt-out, and unfavourable towards such students (Dupoux et al., 2005; Monsen et al., 2014).

Both teachers' professional feelings of academic success and their personal satisfaction related to having treated all students respectfully are important in determining teachers' overall attitudes towards the inclusion of students with EBD in their classrooms.

\section{The School Organization}

Schools employ teachers to carry out a teaching mission. To do this, teachers need support services that vary according to the students in their classes. In this synthesis, the teachers claimed that school organizations have not fulfilled the requirements for the successful inclusion of students with EBD. They claimed that such inclusion leads to a workload that is too heavy, classes that are too large, and climates with too few opportunities for collaboration. They also claimed that they lack the skills and training to include students with EBD in their classrooms.

Teachers' attitudes towards the inclusion of a type of students are closely related to the amount of extra work and extra energy that they have to put in (Cook, 2001; Donohue \& Bornman, 2015; Gaad \& Khan, 2007; Monsen et al., 2014; Rakap \& Kaczmarek, 2010). Some teachers resist accepting students with EBD because such students are a burden in their workloads (Dupoux et al., 2005; Saloviita \& Schaffus, 2016). Gaad \& Khan, (2007) reported that even teachers who had positive attitudes towards inclusion expressed concern about workloads.

Both reducing the number of students in each classroom and adapting classroom spaces for inclusion were found to be necessary step in creating successful inclusion (Dupoux et al., 2005; Gaad \& Khan, 2007; Rakap \& Kaczmarek, 2010; Saloviita \& Schaffus, 2016). Some teachers also complained about schools offering limited opportunities for collaboration (Avramidis \& Kalyva, 2007; Chepel et al., 2016). Inclusion poses classroom-management problems and requires collaboration between general teachers and special educators, as the former are not skilled or trained in educating EBD students (Avramidis \& Kalyva, 2007; Cook, 2001; Dupoux et al., 2005; Grieve, 2009; Khochen \& Radford, 2012; Rakap \& Kaczmarek, 2010; Shevlin et al., 2013).

The teachers also expressed a need for more resources, particularly human support services (Gaad \& Khan, 2007; Saloviita \& Schaffus, 2016; Shevlin et al., 2013). They claimed that the inclusion of children with EBD requires full- 
time support from a SEN team (Grieve, 2009; Monsen et al., 2014). The research informants argued that, to successfully include students with EBD in mainstream classes, school organization must change radically. Time and other resources must be allocated to the mainstream classes, and both exclusive inservice training and increased collaboration between special and general teachers must be provided.

\section{The Attitudes of Others}

Each teacher exists within a specific time, culture, and context. Naturally, the attitudes of those in the surrounding context affect the teachers' attitudes, but this occurs in different ways depending on that context. In this synthesis, the attitudes of peers, other teachers, parents, and the media, as well as the country's specific cultural and historical attitudes, all impact a given teacher's attitudes.

Students with EBD are the least liked group, not only among their teachers but also among their peers (Čagran \& Schmidt, 2011; Cook, 2001; Rakap \& Kaczmarek, 2010). Many parents also have negative attitudes towards these students because they feel that such students' development is given more emphasis than the other students' safety and learning (Avramidis \& Kalyva, 2007; Grieve, 2009; Shevlin et al., 2013). Cook (2001) suggested that because of "reports in popular media that learning disabilities and other mild disabilities are not 'real disabilities,'" $(p, 210)$ students with EBD are often accused of just being lazy or dumb. On the other hand, the diagnosis of a disability can make teachers feel that they are absolved from responsibility. If an EBD student is regarded as disabled, then the responsibility for that student's development is transferred from the teacher to someone else who is more qualified (Grieve, 2009).

Khochen and Radford (2012) indicated that the most significant obstacle to the implementation of inclusion in developing countries is not money or the shortage of physical and human resources but rather the negative attitudes that many classmates, parents, teachers, and people in society hold regarding inclusion. For instance, many people in Lebanon believe that it is not possible for people with disabilities to live normal lives without being isolated (Khochen \& Radford, 2012). In Ghana, because of negative attitudes, many parents do not want their children to share classrooms with students who have SEN or a disability (Gyimah et al., 2009). In Dubai, the majority of teachers' attitudes are influenced by expatriates from the subcontinent, for whom education is a way to gain employment or become an entrepreneur (Gaad \& Khan, 2007). Attitudes tend to be more positive among teachers in rural areas than among those in urban areas. This can be explained by the characteristics of rural society, which is typically more united than urban society and in which people typically know each other well. In a rural community, others can easily learn of any event that happens (Chepel et al., 2016; Dupoux et al., 2005). To sum up, Gaad and Khan (2007) proposed that the media could play a role in encouraging inclusion by informing the public and eliminating misunderstandings about students with SEN. Teachers are affected by other teachers' attitudes; positive attitudes spread (Dupoux et al., 2005).

The way in which students with EBD are constructed by the surrounding society affects teachers' attitudes towards including such students in their 
classrooms. Teachers are a part of both the educational context and the neighbouring context.

\section{Conclusion}

This synthesis research has extend individual studies on teachers' attitudes towards the inclusion of students with SEN by seeking out and synthesizing the research on those attitudes. It also explores some variables that can affect teachers' attitudes. In this synthesis, 15 countries are represented-each with its own distinctive cultural and socio-economic context. Despite these nations' various school systems and cultures, the researchers for 10 of the 15 included studies came to the same conclusion as in previous reviews (Avramidis \& Norwish, 2002; de Boer et al., 2011): Among all SEN students, those with behaviour problems are the most difficult to include in a mainstream classroom. As in previous research (Avramidis \& Norwish, 2002; Bowman, 1986; de Boer et al., 2011; Leyser et al., 1994; Scruggs \& Mastropieri, 1996), the current study indicates that teachers' attitudes towards the inclusion of students with SEN in mainstream schools are dependent on (a) the nature of the disability; (b) the teacher's teaching experience and training, particularly in teaching students with SEN; and (c) the availability of support services at the classroom and school levels. The latter two factors depend on the nature of the disability, and the effects of both are escalated when it comes to students with EBD. The overall conclusions of this synthesis are (a) that teachers feel that they do not have the prerequisites to successfully include students with EBD, and (b) that the impracticability is most prominent when teachers nevertheless try to include such students.

\section{Main conclusions}

The first conclusion is that teachers explain the nature of the problem with including students with EBD (when behaviour is stressed) always impact their classmates and teachers. This in turn affects themselves, though only in relation to others. Thus, students with EBD are different from those in other SEN categories. Differences should be valued, but it is quite difficult for teachers to value students' behaviour which can physically endanger, threaten, and disturb the other students in the class, as well as disrupt the learning process. To monitor and correct such behaviour requires teachers' time and focus, using up the teachers' and other students' time and shifting the focus away from learning. The reactions of the teachers and other students are an evident consequence of this difficulty itself.

Secondly, all teachers must perform certain professional tasks. For instance, they are supposed to teach students in the best possible manner according to the curriculum. This can be done in many ways but, it requires that the students feel safe and secure and that the teacher have the opportunity to arrange the lessons beforehand to ensure that all students learn. When teachers cannot do this, they inevitably feel frustration and insufficiency. Teachers want to make their classrooms calm and secure while providing a rewarding learning atmosphere. Disruptions, reprimands, and behavioural discussions take time, make the classroom atmosphere unsound and cause the class to be unfocused. 
A third conclusion is that teachers feel that their school organizations have left them to handle students with EBD on their own. In this review, the teachers mentioned myriad supports that they need to ensure successful (or at least manageable) inclusion of EBD students, but those supports have not been provided. They need sufficient skilful classroom personnel, adaptable classrooms, fewer students in each class, more time for planning and reflection, and more time for collaboration with resource personnel; without which successful inclusion of such students is not possible. The teachers also feel that they have not been given enough in-service training or skills to work with these students. Without both human and economic support from school organizations, the inclusion of students with EBD will continue to cause difficulties and hardship for students with EBD themselves, their teachers, and their classmates.

Lastly, the included studies have shown how others' attitudes and the prevailing discourses can affect teachers. Even if the teaching situations are similar in all countries, those countries' distinct discourses shape the understandings and attitudes. Gaad and Khan (2007) explained, "Culture plays a very important role here, in some cultures students who are naughty are considered active students but in some cultures, these students are labelled as having behavioural problems." (p. 105). Further research and more actual descriptions of EBD could challenge the prevailing discourses. When Dupoux et al. (2005) described how teachers' attitudes became more positive if their colleagues had positive attitudes, their conclusion was that the media could do more to challenge existing attitudes and to encourage more positive attitudes among both teachers and the surrounding society.

\section{Further research}

There is, however, a need for further research, especially regarding the kinds of support that school organizations should focus on providing for their teachers. Involving the teachers in the research process (in their classrooms and schools) would provide a more complete picture of how the working and learning situations could improve for the EBD students themselves, as well as for their teachers and classmates. Some potential areas of are (a) the optimal student-toteacher ratio when students with EBD are included in a class, (b) the appropriate skills and assignments for additional personnel, (c) the ways to most effectively balance teachers' workloads when students with EBD are included in a class, and (d) the appropriate forms of collaboration and power relations among school management, the student health and support team, and mainstream teachers.

Since the 1990s, the educational agenda has featured the inclusion of all students, regardless their individual difficulties, in mainstream classrooms. Teachers' attitudes are of great importance in the successful continuation of this process. When teachers' working conditions cause them to hold negative attitudes, especially towards the inclusion of students with EBD, there is a risk that this will spread to teachers' attitudes towards inclusion as a whole, as Monsen et al. (2014) clearly highlighted in this quotation:

[T] he issue of teachers being least willing to include children with behavioral or multiple difficulties then holds implications for the success 
of inclusive education, and that the teachers' negative attitudes of students with EBD have implications for the success of the overall inclusive education (p. 125).

\section{References}

Avramidis, E,. \& Kalyva, E. (2007). The influence of teaching experience and professional development on Greek teachers' attitudes towards inclusion. European Journal of Special Needs Education, 367-389. https:// doi.org/10.1080/08856250701649989

Avramidis, E., \& Norwich, B. (2002). Teachers' attitudes towards integration/inclusion: A review of the literature. European Journal of Special Needs Education, 17(2), 12949. https://doi.org/10.1080/08856250210129056

Boaz, A., \& Sidford A. (2006). Reviewing existing research. In G. Nigel (Ed.). From postgraduate to social scientist (pp. 7-24). London: Sage Research Methods Database. https://doi.org/10.4135/9781849209182.n2

Bornman, J., \& Donohue, D. K. (2013). South African teachers' attitudes toward learners with barriers to learning: Attention-deficit and hyperactivity disorder and little or no functional speech. International Journal of Disability, Development and Education, 60(2), 85-104. https:// doi.org/10.1080/1034912X.2013.786554

Bowman, I. (1986). Teacher training and the integration of handicapped pupils: Some findings from a fourteen nation UNESCO study. European Journal of Special Needs Education, 1, 29-38. https://doi.org/10.1080/0885625860010105

Braun, V., \& Clarke, V. (2006). Using thematic analysis in psychology. Qualitative Research in Psychology, 3(2), 77-101. https://doi.org/10.1191/1478088706qp063oa

Čagran, B., \& Schmidt, M. (2011). Attitudes of Slovene teachers towards the inclusion of pupils with different types of special needs in primary school. Educational Studies, 37(2), 171-195. https://doi.org/10.1080/03055698.2010.506319

Chepel, T., Aubakirova, S., \& Kulevtsova, T. (2016). The study of teachers' attitudes towards inclusive education practice: The case of Russia. The New Educational Review, 45(3), 235-248.

Cook, B. G. (2001). A comparison of teachers' attitudes toward their included students with mild and severe disabilities. Journal of Special Education, 34(4), 203-213. https://doi.org/10.1177/002246690103400403

Cook, B. G., \& Cameron, D. L. (2010). Inclusive teachers' concern and rejection toward their students investigating the validity of ratings and comparing student groups. Remedial and Special Education, 31(2), 67-76. https://doi.org/10.1177/0741932508324402

de Boer, A., Pijl, S. J., \& Minnaert, A. (2011). Regular primary schoolteachers' attitudes towards inclusive education: A review of the literature. International Journal of Inclusive Education, 1(1), 1-24. https://doi.org/10.1080/13603110903030089

Department for Education. (1994). Emotional and behavioural difficulties. Circular 9/94. London, England.

Donohue, D. K., \& Bornman, J. (2015). South African teachers' attitudes toward the inclusion of learners with different abilities in mainstream classrooms. International Journal of Disability, Development and Education, 62(1), 42-59. https://doi.org/10.1080/1034912x.2014.985638

Dupoux, E., Wolma, C., \& Estrada, E. (2005). Teachers' attitudes toward integration of students with disabilities in Haiti and the United States. International Journal of Disability, Development and Education, 52(1), 45-60. https://doi.org/10.1080/10349120500071894

Elsevier (2017). Scopus. Retrieved from https://www.elsevier.com/solutions/scopus 
Enslin, P., \& Hedge, N. (2010). Inclusion and diversity. In R. Bailey, R. Barrow, D. Carr, \& C. MacCarthy (Eds.), The Sage handbook of philosophy of education (pp. 385-401). London, England: Sage. https:// doi.org/10.4135/9781446200872.n26

Evans, J., \& Lunt, I. (2002). Inclusive education: Are there limits? European Journal of Special Needs Education, 17(1), 1-14. https://doi.org/10.1080/08856250110098980

Fink, A. (2005). Conducting research literature reviews: From the Internet to paper. New York, NY: SAGE.

Gaad, E., \& Khan L. (2007). Primary mainstream teachers' attitudes towards inclusion of students with special educational needs in the private sector: A perspective from Dubai. International Journal of Special Education, 22(2), 95-109.

Grieve, A. M. (2009). Teachers' beliefs about inappropriate behaviour: Challenging attitudes? Journal of Research in Special Educational Needs, 9(3), 173-179. https://doi.org/10.1111/j.1471-3802.2009.01130.x

Gyimah, E. K., Sugden, D., \& Pearson, S. (2009). Inclusion of children with special educational needs in mainstream schools in Ghana: Influence of teachers' and children's characteristics. International Journal of Inclusive Education, 13(8), 787804. https:// doi.org/10.1080/13603110802110313

Khochen, M., \& Radford, J. (2012). Attitudes of teachers and head teachers towards inclusion in Lebanon. International Journal of Inclusive Education, 16(2), 139-153. https://doi.org/10.1080/13603111003671665

Leyser, Y., Kapperman, G., \& Keller, R. (1994). Teacher attitude toward mainstreaming: A cross-cultural study in six nations. European Journal of Special Needs Education, 9(1), 1-15. https://doi.org/10.1080/0885625940090101

Maggin, D. M., Wehby, J. H., Farmer, T. W., \& Brooks, D. S. (2016). Intensive interventions for students with emotional and behavioral disorders: Issues, theory, and future directions. Journal of Emotional and Behavioral Disorders, 24(3), 127-137. https://doi.org/10.1177/1063426616661498

Major, C. H., \& Savin-Baden, M. (2010). An introduction to qualitative research synthesis: Managing the information explosion in social science research. New York, NY: Routledge. https://doi.org/10.4324/9780203497555

Monsen, J. J., Ewing, D. L., \& Kwoka, M. (2014). Teachers' attitudes towards inclusion, perceived adequacy of support and classroom learning environment. Learning Environment Research, 17, 113-126. https://doi.org/10.1007/s10984-013-9144-8

National Board of Health and Welfare [Sweden]. (2010). Barn som utmanar: Barn med $A D H D$ och andra beteendeproblem. Retrieved from http://www.socialstyrelsen.se/publikationer2010/2010-3-6

Nilholm, C. (2017). SMART. Ett sätt att genomföra forskningsöversikter. Lund, Sweden: Studentlitteratur.

Prisma (2017). Retrieved from http:/ / www.prisma-statements.org

Rakap, S., \& Kaczmarek, L. (2010). Teachers' attitudes towards inclusion in Turkey. European Journal of Special Needs Education, 25(1), 59-75. https://doi.org/10.1080/08856250903450848

Saloviita, T., \& Schaffus, T. (2016). Teacher attitudes towards inclusive education in Finland and Brandenburg, Germany and the issue of extra work. European Journal of Special Needs Education, 31(4), 458-471. https://doi.org/10.1080/08856257.2016.1194569

Scruggs, T. E., \& Mastropieri, M. A. (1996). Teacher perceptions of mainstreaming/inclusion: A research synthesis. Exceptional Children, 63(1), 5974. https://doi.org/10.1177/001440299606300106

Shevlin, M., Winter, E., \& Flynn, P. (2013). Developing inclusive practice: Teacher perceptions of opportunities and constraints in the Republic of Ireland. International Journal of Inclusive Education, 17(10), 1119-1133. https://doi.org/10.1080/13603116.2012.742143 
Stoutjesdijk, R., Scholte, E. M., \& Swaab, H. (2016). Impact of family functioning on classroom problem behavior of children with emotional and behavioral disorders in special education. Journal of Emotional and Behavioral Disorders, 24(4): 199-210. https:// doi.org/10.1177/1063426615587262

Thomas, G., \& Loxley, A. (2001). Deconstructing special education and constructing inclusion. Philadelphia, PA: Open University Press.

UNESCO. (1990). World declaration on education for all and framework for action to meet basic learning needs. International consultative forum on education for all. Paris, France: UNESCO.

UNESCO. (1994). The Salamanca statement and framework for action on special needs education. New York, NY: UNESCO. 